\title{
Late Pleistocene climate evolution in Southeastern Europe recorded by soil bacterial membrane lipids in Serbian loess
}

\author{
Laura T. Schreuder ${ }^{\mathrm{a}, \mathrm{b}, *}$, Christiaan J. Beets ${ }^{\mathrm{a}}$, Maarten A. Prins ${ }^{\mathrm{a}}$, Christine Hatté ${ }^{\mathrm{c}}$, Francien Peterse ${ }^{\mathrm{b}}$ \\ a VU University, Faculty of Earth and Life Sciences, De Boelelaan 1085, 1081 HV, Amsterdam, The Netherlands \\ b Utrecht University, Department of Earth Sciences, Heidelberglaan 2, 3584 CS Utrecht, The Netherlands \\ c Laboratoire des Sciences du Climat et de l'Environnement, UMR 8212 CEA-CNRS-UVSQ Université Paris-Saclay, F-91198 Gif-sur-Yvette, France
}

\section{A R T I C L E I N F O}

\section{Article history:}

Received 16 October 2015

Received in revised form 5 February 2016

Accepted 7 February 2016

Available online 17 February 2016

\section{Keywords:}

Air temperature

Branched glycerol dialkyl glycerol tetraether (GDGT) membrane lipids

Carpathian Basin

Loess

Paleoclimate

\begin{abstract}
A B S T R A C T
Loess-paleosol sequences in the Vojvodina region in the southeastern Carpathian Basin have been intensively studied to obtain a high-resolution stratigraphical framework for the Upper Pleistocene in this part of Europe. In these studies, millennial-scale sedimentation variations in the Upper Pleniglacial have been coupled to the Greenland Ice dust record, indicating that the rapid climate variability characterizing the North Atlantic and Greenland areas, is reflected in the loess deposits at the southern edge of the European loess belt. Rapid variations were recently also reported for the stable isotopic composition of organic matter in the Surduk loess-paleosol sequence, located in the Vojvodina region, and were interpreted as episodes of increased $\mathrm{C}_{4}$-vegetation over the last glacial period. Based on potential coinciding changes in oceanic and atmospheric circulation patterns, these episodes were attributed to plant moisture stress rather than by fluctuations in temperature, although exclusive proof has not yet been provided. Here we report a high-resolution record of continental air temperature and precipitation over the past 40,000 years based on soil bacterial lipid signatures preserved in the Surduk loesspaleosol sequence. Our temperature record shows a gradual warming trend, suggesting that moisture availability indeed seems to be the main factor driving the excursions to $\mathrm{C}_{4}$-vegetation around Surduk. We also find that continental air temperature changes in this region may be seasonally biased, and were driven by regional influences rather than by Northern Hemisphere climate forcings, likely as a result of the inland isolation of the Carpathian Basin by surrounding mountains. Support for a regional climate driver comes from comparison of our lipidbased temperature and precipitation records with similar records from the near-by Crvenka loess-paleosol sequence, which resemble the climatic trends recorded at Surduk.
\end{abstract}

(c) 2016 Elsevier B.V. All rights reserved.

\section{Introduction}

During the Quaternary, windblown dust has accumulated as loess deposits over large parts of Europe and Asia. Especially on the Chinese Loess Plateau these deposits have been well studied, where the alternations of loess and paleosol layers have been related to cold and dry glacials and warm and wet interglacials, respectively (e.g. An, 2000). But also in Europe, loess-paleosol sequences are widespread (Haase et al., 2007) and have been studied to gain more insight into Quaternary climate change, especially the last glacial period (e.g. Buggle et al., 2009; Antoine et al., 2001; Rousseau et al., 2002). In Western Europe, loess grain size variations and the alternation of loess and gleys in the sequences have been linked to the dust record of the Greenland ice core (Rousseau et al., 2007), suggesting a connection between the atmospheric circulation and associated wind regimes in the North Atlantic

\footnotetext{
* Corresponding author at: NIOZ Royal Netherlands Institute for Sea Research, Department of Marine Microbiology and Biogeochemistry, and Utrecht University, P.O. Box 59, 1790 AB, Den Burg (Texel), The Netherlands.

E-mail address: laura.schreuder@nioz.nl (L.T. Schreuder).
}

and Europe. This connection is also visible in loess-paleosol sequences located in the Carpathian Basin in Southeastern Europe, where abrupt increases in loess grain size indicate a succession of short events during the Upper Pleniglacial (ca. 37-20 kyr BP), reflecting the variations in aeolian dynamics related to rapid climate variability, as also recorded in North Atlantic and Greenland records (e.g. Marković et al., 2005, 2008; Antoine et al., 2009; Stevens et al., 2011).

A recent study focusing on the Surduk loess-paleosol sequence, located in the southern part of the Carpathian Basin (Fig. 1), showed that also the stable isotopic composition of organic carbon $\left(\delta^{13} \mathrm{C}\right)$ has recorded similarly rapid changes (Hatté et al., 2013). The isotope record indicates several episodes of ${ }^{13} \mathrm{C}$ enrichment during the Late Pleistocene, which have been interpreted as temporary dominance of $C_{4}$ vegetation in this region. The excursions to $C_{4}$ vegetation have been explained by dry and short summers caused by coinciding changes in oceanic and atmospheric circulation patterns, unfavorable for moisture transport from the Mediterranean Sea and Atlantic, and consequently resulting in less precipitation on the Balkans. However, exclusive proof for moisture availability as main driver of vegetation change is hard to obtain, as it is difficult to disentangle whether the variability in the 


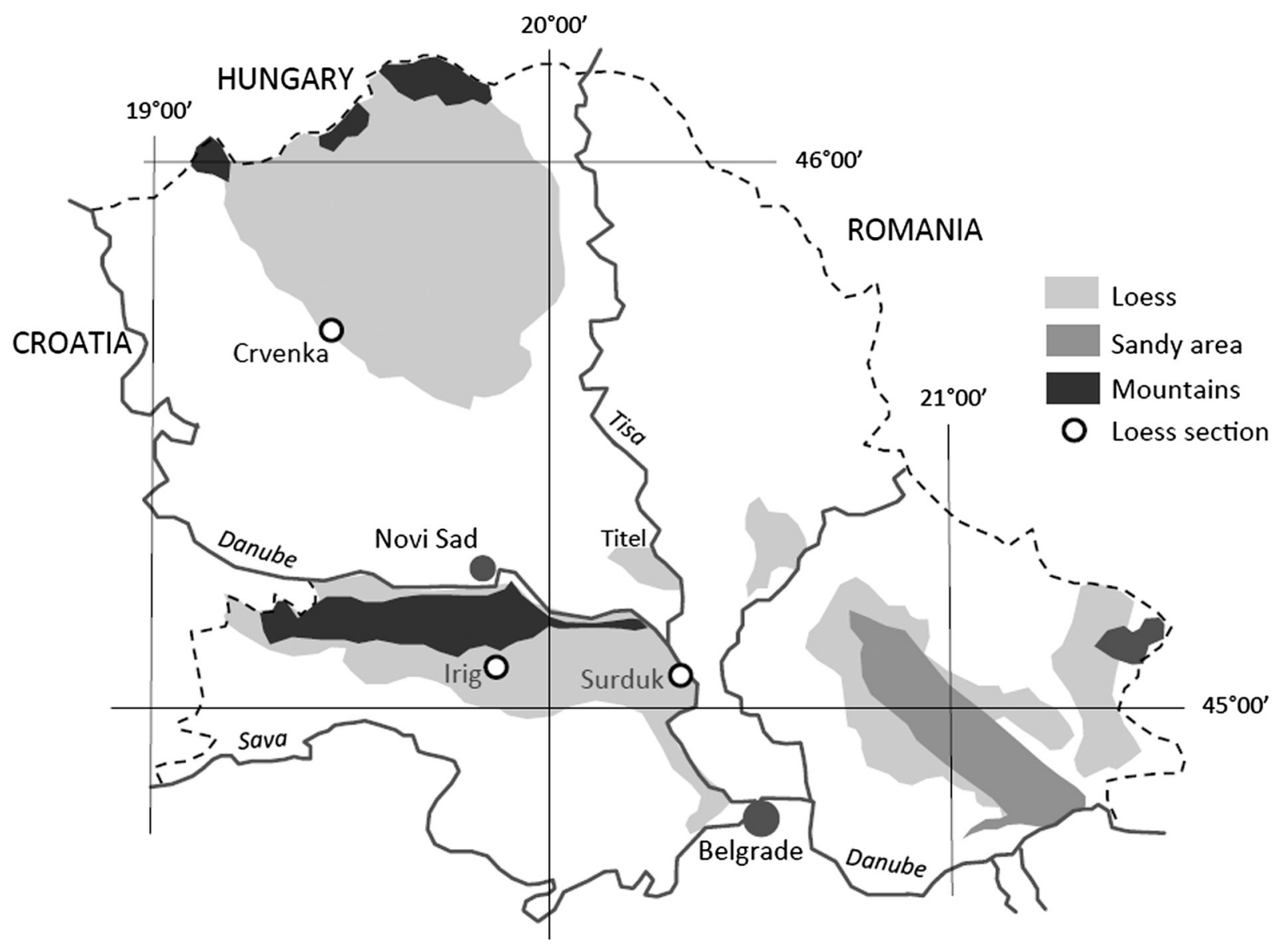

Fig. 1. Map of the Carpathian Basin with the location of the Surduk, Crvenka and Irig loess-paleosol sequences.

$\delta^{13} \mathrm{C}$ record is driven by changes in temperature or precipitation based only on variations in grain size distributions or total organic carbon content (Hatté et al., 2013).

In order to further identify the driver(s) of sudden vegetation change in this area, the occurrence and relative distribution of branched glycerol dialkyl glycerol tetraethers (brGDGTs; Fig. 2) have been analyzed throughout the same loess-paleosol sequence at Surduk. BrGDGTs are membrane lipids produced by soil bacteria that occur ubiquitously in soils and peat (Weijers et al., 2006), and adapt the molecular structure of their membrane to changes in mean air temperature (MAT) and soil pH (Weijers et al., 2007a). Hence, past changes in MAT and soil $\mathrm{pH}$ can be reconstructed by using the MBT (methylation of branched tetraethers) and the CBT (cyclisation of branched tetraethers) indices, based on the amount of methyl branches (4-6) and cyclopentyl moieties (0-2) of the brGDGTs, respectively (Weijers et al., 2007a). The strength of this method is that variations in precipitation-induced soil $\mathrm{pH}$ and MAT are reconstructed based on the same suite of molecules, which is ideal to disentangle the influence of these two environmental parameters on e.g. vegetation change. Furthermore, also the relative abundance of brGDGTs compared to that of crenarchaeol (Fig. 2), an isoprenoid GDGT that is produced in soils by ammonia oxidizing archaea, has been shown to relate with soil moisture availability (e.g. Xie et al., 2012; Dirghangi et al., 2013), and can be quantified in the Branched and Isoprenoid Tetraether (BIT) index (Hopmans et al., 2004). Together with soil pH, the BIT index can thus be used as indicator for past precipitation changes. Recent studies from the Chinese Loess Plateau have indicated that brGDGTs indeed record past climatic changes, both in temperature as well as in precipitation intensity (e.g. Jia et al., 2013; Peterse et al., 2011, 2014).

A first attempt to reconstruct precipitation and MAT using brGDGTs in the nearby Crvenka loess-paleosol sequence indicated an early warming and higher than expected air temperatures during the past glacial-interglacial transition (Zech et al., 2012). The unexpected trends were attributed to a.o. incomplete peak separation of co-eluting brGDGT isomers during analysis using high performance liquid chromatography (HPLC), complicating the determination of the exact abundance of each brGDGT in the obtained chromatogram (Zech et al., 2012). This issue has recently been resolved by De Jonge et al. (2014), who proposed an optimized HPLC method that enables the separation of these isomers, adding to the reliability of the generated proxy records. Moreover, identification of the isomers (De Jonge et al., 2013) indicated that brGDGTs with a methyl branch on the $5^{\prime}$ or the $6^{\prime}$ position are related to temperature and $\mathrm{pH}$, respectively, further separating the influence of these environmental parameters, and the accuracy of their use as paleothermometer (De Jonge et al., 2014). Hence, the use of this new method to generate GDGT-based climate records may provide new insights on past precipitation and temperature variability in continental Europe, and their subsequent influence on past vegetation dynamics.

\section{Material and methods}

\subsection{Study site}

The Surduk sequence is located in the north of Serbia, in the Vojvodina province in the southeastern part of the Carpathian Basin $\left(45^{\circ} 40\right.$ $\mathrm{N}, 20^{\circ} 20^{\prime} \mathrm{E} ; 111 \mathrm{~m}$ above sea-level; Fig. 1). The Vojvodina area is characterized by the presence of thick loess-paleosol sequences mainly outcropping as high loess cliffs along the western bank of the Danube River and at the confluence between the Danube and tributaries, including the Tisa River east of the Titel Plateau (Fig. 1) (Marković et al., 2008; Antoine et al., 2009). The area currently lies at the border between Atlantic, Continental and Mediterranean climate zones and small 
Ia $m / z 1022$
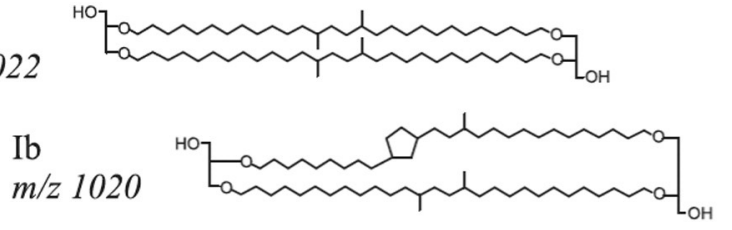

Ic $m / 21018$

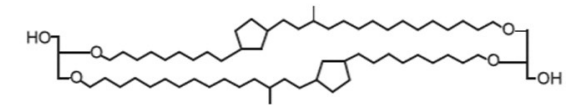

IIa $m / z 1036$

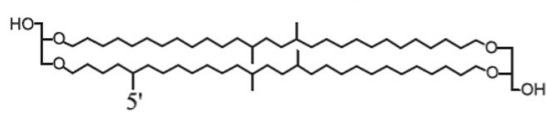

IIa' $m / z 1036$

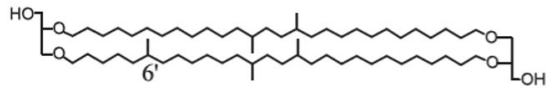

$\mathrm{IIb}$

$m / z 1034$

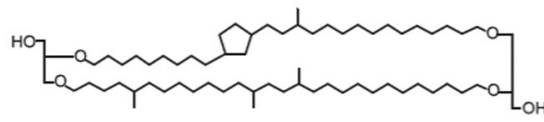

IIb' $\mathrm{m} / \mathrm{z} 1034$

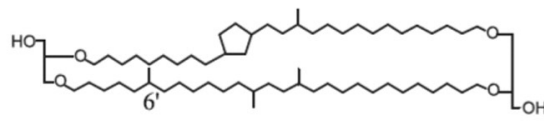

IIc $\mathrm{m} / \mathrm{z} 1032$

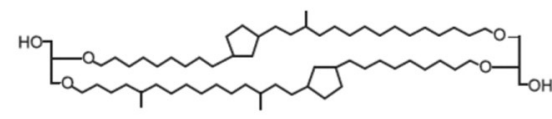

IIc' $\mathrm{m} / \mathrm{z} 1032$

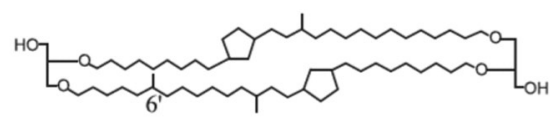

IIIa $\mathrm{m} / \mathrm{z} 1050$
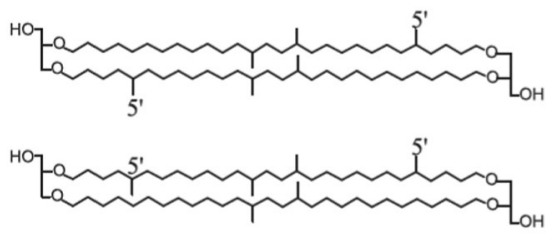

IIIa'

$\mathrm{m} / \mathrm{z} 1050$
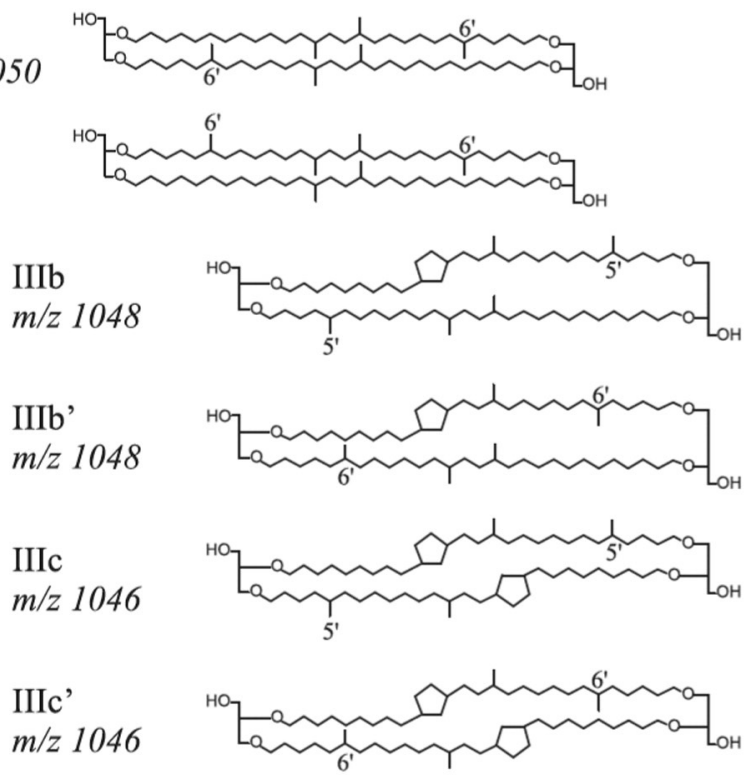

IV

$\mathrm{m} / \mathrm{z} 1292$

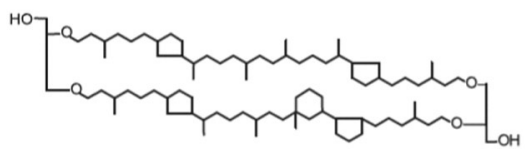

Fig. 2. Molecular structures of brGDGTs (I-III) and crenarchaeol (IV). Figure adapted from De Jonge et al. (2014). changes in the relative influence of associated atmospheric systems will have significant impacts on the region's climate (Ducic and Radovanović, 2005). At present, the site is mostly under a Mediterranean climate influence, and has an annual mean air temperature of $11^{\circ} \mathrm{C}$, varying between $-1{ }^{\circ} \mathrm{C}$ in January and $21^{\circ} \mathrm{C}$ in July, on average (Hrnjak et al., 2014). The annual rainfall is ca. $600 \mathrm{~mm}$ (Tošić et al., 2014). With ca. 120 rainy days per year, the area has no strong seasonality with a dry summer season and/or a long and cold winter (Hatté et al., 2013).

The Surduk loess-paleosol sequence consists of alternation of typical loess, tundra gleys and paleosols over $20 \mathrm{~m}$. It was sampled in 2009 in $5 \mathrm{~cm}$ resolution after harsh cleaning of the section, and is described in detail by Antoine et al. (2009) and Fuchs et al. (2008). The sequence was subdivided into 14 sedimentary and pedological units (Antoine et al., 2009), and more recently, Marković et al. (2015) defined a new Danube Basin wide loess stratigraphy, allowing correlation of the data with Oxygen Isotope Stage (OIS) intervals. Previous studies have reported grain size, $\mathrm{CaCO}_{3}$ and TOC content of the sediment where coarse material (over $160 \mu \mathrm{m}$ ) was sieved off, as well as bulk $\delta^{13} \mathrm{C}$ composition for this sequence (Antoine et al., 2009; Hatté et al., 2013). The current study was performed on aliquot of the same samples that were used for both sedimentology and isotopic studies.

\subsection{BrGDGT analysis}

The typical loess, gley and paleosols $(<160 \mu \mathrm{m})$ were homogenized with a mortar and pestle, after which brGDGTs were extracted $(3 \times)$ from $22 \mathrm{~g}$ homogenized loess and paleosol with dichloromethane (DCM):methanol $(9: 1, v / v)$ using an accelerated solvent extractor (ASE 200, Dionex) at $100{ }^{\circ} \mathrm{C}$ and $7.6 \times 10^{6} \mathrm{~Pa}$. The total lipid extracts were dried under $\mathrm{N}_{2}$ and separated into an apolar and a polar fraction by passing them over an activated $\mathrm{Al}_{2} \mathrm{O}_{3}$ column using hexane:DCM $(9: 1, v / v)$ and $\mathrm{DCM}: \mathrm{MeOH}(1: 1, v / v)$ as eluents, respectively. The polar fraction, containing the brGDGTs, was dried under $\mathrm{N}_{2}$, redissolved in hexane:isopropanol $(99: 1, v / v)$ and passed over a $0.45 \mu \mathrm{m}$ PTFE filter. BrGDGTs were analyzed using an Agilent 1290 Infinity ultra high performance liquid chromatography (UHPLC) coupled to an Agilent 6130 single quadrupole mass detector (MS) according to Hopmans et al. (2016). In short, separation of the brGDGTs was performed on two silica Waters Acquity UPLC HEB Hilic $(1.7 \mu \mathrm{m}, 2.1 \mathrm{~mm} \times 150 \mathrm{~mm})$ columns at $30^{\circ} \mathrm{C}$, preceded by a guard column of the same material. GDGTs were separated isocratically using $82 \% \mathrm{~A}$ and $18 \% \mathrm{~B}$ for $25 \mathrm{~min}$ at a flow rate of $0.2 \mathrm{ml} / \mathrm{min}$, and then with a linear gradient to $70 \% \mathrm{~A}$ and $30 \% \mathrm{~B}$ for $25 \mathrm{~min}$, where $\mathrm{A}=$ hexane and $\mathrm{B}=$ hexane:isopropanol 9:1. The GDGTs were ionized using atmospheric pressure chemical ionization with the following source conditions: gas temperature $200^{\circ} \mathrm{C}$, vaporizer temperature $400^{\circ} \mathrm{C}$, drying gas $\left(\mathrm{N}_{2}\right)$ flow $6 \mathrm{l} / \mathrm{min}$, Nebulizer pressure $25 \mathrm{psi}$, capillary voltage $3500 \mathrm{~V}$, corona current $5.0 \mu \mathrm{A}$. The $[\mathrm{M}+\mathrm{H}]^{+}$ ions were detected in selected ion monitoring (SIM) mode, and quantified using Chemstation software B.04.02.

\subsection{GDGT-based proxy calculations}

The MAT and soil pH of the Surduk loess-paleosol sequence were calculated using fractional brGDGT abundances and the following equations and transfer functions according to the most recent calibration of De Jonge et al. (2014). Roman numerals in the equations refer to the molecular structures in Fig. 2.

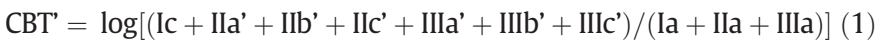

$\mathrm{pH}=7.15+1.59 * \mathrm{CBT}^{\prime}$

$\mathrm{MAT}_{\mathrm{mr}}=7.17+17.1 *[\mathrm{Ia}]+25.9 *[\mathrm{Ib}]+34.4 *[\mathrm{Ic}]-28.6 *[\mathrm{Ila}]$ 
The BIT index was calculated according to Hopmans et al. (2004), using both 5- and 6-methyl brGDGTs:

BIT $=($ Ia + IIa + IIa' + IIIa + IIIa') $/($ IV + Ia + IIa + IIa' + IIla + IIIa' $)$

\section{Results}

In the loess interval between 1555 and $1290 \mathrm{~cm}$ depth, roughly corresponding to the Lower Pleniglacial and the early part of the Middle Pleniglacial complex, the concentration of GDGTs was below detection limit (10 samples), so that proxy calculation was not possible for this part of the sequence. However, GDGT abundance was sufficient in 103 out of 111 remaining samples (Supplementary Table 1 ) to calculate air temperature, pH, and BIT index values (Fig. 3; Supplementary Table 2).

The reconstructed air temperature record of the Surduk sequence varies between $7{ }^{\circ} \mathrm{C}$ and $20^{\circ} \mathrm{C}$ (Fig. 3), with highest temperatures reconstructed for the top of unit L1LL2, correlating with OIS 2 (Marković et al., 2015), and lowest for the top of unit L1SS1, correlating with OIS 3 (Marković et al., 2015). Warm conditions were reconstructed for unit S1, correlating with OIS 5, a cooling interval at the end of OIS 3, followed by a gradual increase in temperature until the end of OIS 2. Although the brGDGT-derived temperature for the surface sample matches modern MAT, the upper meter of the sequence was disturbed by a few deep root tracks, so that this part of the record must be interpreted with care (Hatté et al., 2013). The pH record ranges from 6.6 to 7.8, with highest values reconstructed for unit $\mathrm{S} 1$. The BIT-index varies between 0.55 in OIS 3 , and 0.93 at the end of OIS 2.

The uppermost sample is an outlier in all three proxy records (Fig. 3), likely due to afore mentioned disturbance by plant roots (Hatté et al., 2013). Therefore, this data point is excluded from further discussion.

\section{Discussion}

\subsection{Continental climate evolution recorded in the Surduk sequence}

Along the loess sequence, reconstructed temperatures are higher than expected based on modern MAT, reaching $20^{\circ} \mathrm{C}$ at the end of the equivalent OIS 2 (Fig. 3). We will, therefore, focus on the trends in our records, and mainly discuss our results in terms of higher/lower, cooler/warmer, as has also been done for studies in China (e.g. Peterse et al., 2014). Additionally, potential biases of the brGDGT-records will be evaluated.

Based on trends in the proxy records obtained from the Surduk Sequence, climate evolution in the Vojvodina region can be divided into three main stages, i.e. OIS 5, OIS 4-first part of OIS 3, and the period from the second part of OIS 3 to OIS 1 (Fig. 3).

\subsubsection{OIS 5}

In the Surduk sequence, OIS 5 is represented by a well-developed paleosol with a low sand-percentage (around 5\%; unit S1 in Fig. 3), indicating low-energy (aeolian) deposition, as is characteristic for paleosols in this region (e.g. Marković et al., 2008). Despite the high resolution of our GDGT-proxy records, the five substages of OIS 5 generally observed in the marine environment (e.g. global benthic stack LR04; Lisiecki and Raymo, 2005) or ice core records (e.g. Petit et al., 1999) cannot be recognized in the Surduk sequence. Instead, reconstructed temperatures indicate a gradual decrease from $18^{\circ} \mathrm{C}$ at the onset of OIS 5 towards $14{ }^{\circ} \mathrm{C}$ at the transition into OIS 4 (Fig. 3). It may be that brGDGTs have only recorded the warm stages ( $5 e, 5 c$ and $5 a$ ) in the Surduk sequence, and that the cold stages were either not strong enough to be recorded in brGDGTs, or that climatic conditions were unfavorable to brGDGT-

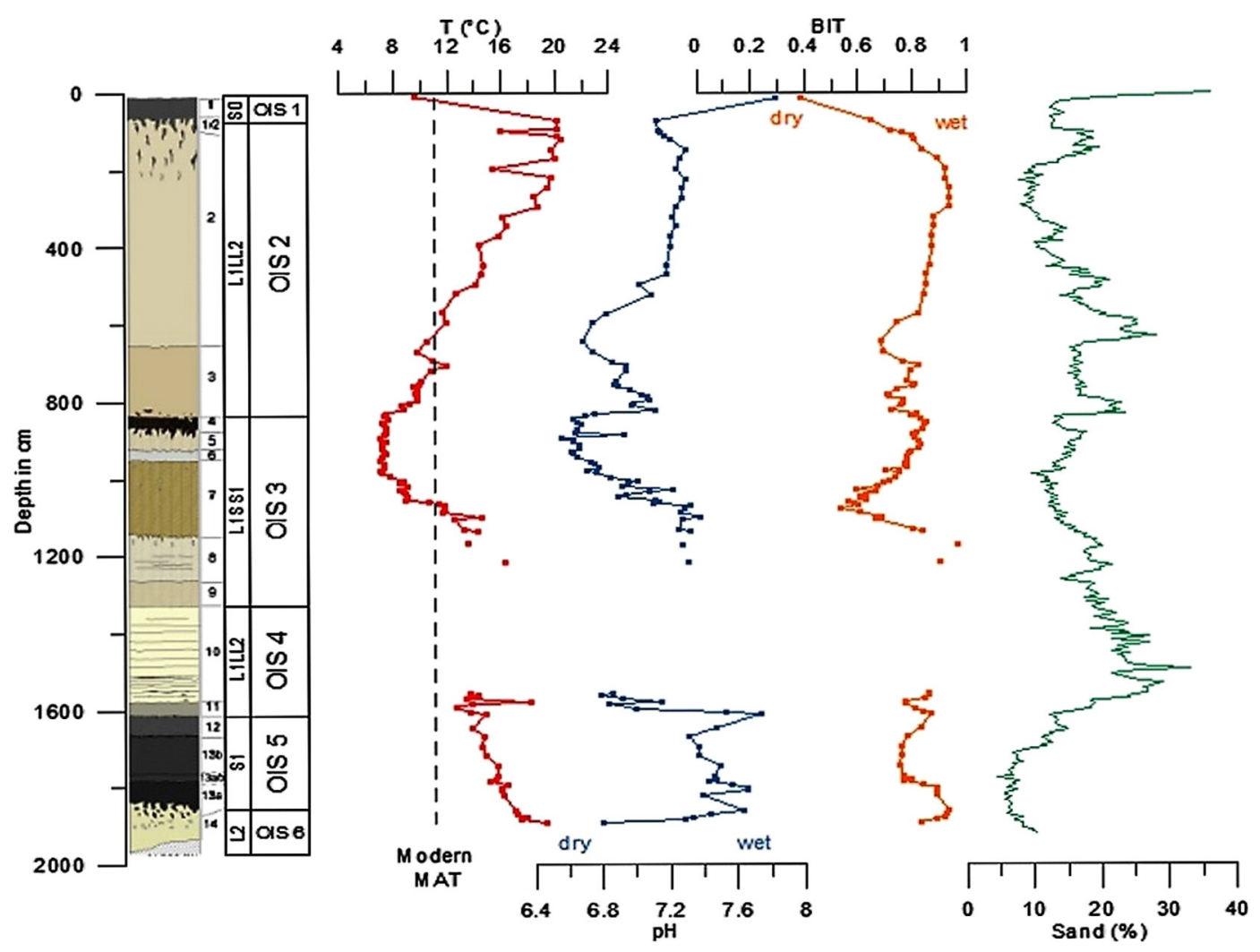

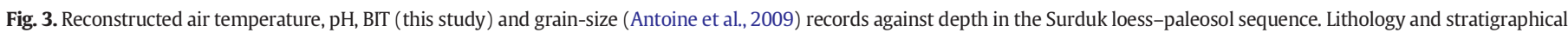
units are adapted from Antoine et al. (2009) and Marković et al. (2015). 
producing organisms to be reflected in the record. This would then result in the decreasing trend observed here, as $5 \mathrm{e}$ is generally recognized as the warmest stage and $5 \mathrm{c}$ and $5 \mathrm{a}$ were slightly cooler (Shackleton, 1969). Reconstructed temperature for OIS 5 is lower than during the Holocene Optimum (ca. 9 ka to $4 \mathrm{ka}$ ), whereas higher temperatures are expected based on aforementioned established climate records. The layer covering OIS 5 in the Surduk loess-paleosol sequence represents the Basal soil complex, a well-developed, weathered paleosol that is generally found in other sequences in this region (Marković et al., 2008). The formation of this layer is attributed to warm and humid conditions in combination with a very low sedimentation rate (about $8 \mathrm{~cm} / \mathrm{kyr}$ ) (Hatté et al., 2013). Hence, these conditions have probably led to increased soil microbial activity and bioturbation, consequently mixing the GDGTs and thus altering and/or smoothening the climate signal in this layer.

Even though the CBT'-based soil $\mathrm{pH}$ record shows more variation than the temperature record, the individual OIS 5 substages cannot be recognized. The record varies within $0.3 \mathrm{pH}$ unit during the first part of OIS 5 , followed by a peak in $\mathrm{pH}$ and a steep drop of about $1 \mathrm{pH}$ unit at the OIS 5-OIS 4 transition. As precipitation has an important influence on the $\mathrm{pH}$ of a soil, similar brGDGT-derived $\mathrm{pH}$ records have been used to infer past changes in precipitation intensity (e.g. Weijers et al., 2007b; Peterse et al., 2014). In addition, a recent study on a loess-paleosol sequence from the Chinese Loess Plateau directly linked the CBT index to monsoon precipitation amounts (Wang et al., 2014), supporting the interpretation of the $\mathrm{pH}$ records as one for precipitation dynamics. Notably, reconstructed $\mathrm{pH}$ for loess-paleosol sequences appears to show an opposite relation with precipitation compared to that for 'normal soils', as the highest reconstructed soil pH occur during periods with presumed wetter conditions, and lower reconstructed $\mathrm{pH}$ values with drier periods (cf. Peterse et al., 2014). This opposite relation may be explained by the generally high $\mathrm{CaCO}_{3}$ content of loess upon deposition: during periods of increased precipitation, the $\mathrm{CaCO}_{3}$ deposited with the loess will gradually dissolve, thereby temporarily increasing the soil $\mathrm{pH}$, which is recorded by the brGDGT-producing bacteria. After a prolonged period of increased precipitation, $\mathrm{CaCO}_{3}$ will be leached from the soil, leading to a decrease in soil pH. Present day soil $\mathrm{pH}$ thus reflects the lower $\mathrm{pH}$ after carbonate leaching, whereas the fossil brGDGTs reflect the increased $\mathrm{pH}$ conditions due to $\mathrm{CaCO}_{3}$ dissolution they experienced during production, hence creating an inverse paleo-pH record. Following this line of reasoning, the relatively high reconstructed $\mathrm{pH}$ values during OIS 5 may thus be interpreted as wet conditions.

Such wet conditions are also reflected by the high BIT index values during this period (Fig. 3). Although the BIT index was originally designed to determine the contribution of soil organic carbon into a marine system (Hopmans et al., 2004), soil-based BIT values have recently been shown to reflect (soil) moisture availability along a precipitation transect in the USA, whereby BIT decreases with increasing aridity (e.g. Dirghangi et al., 2013). Thus, the $\mathrm{pH}$ and BIT index records support the wet conditions during OIS 5 (Fig. 3) as inferred from the formation of a paleosol layer (e.g. Marković et al., 2008).

\subsubsection{OIS 4 - OIS 3}

The concentration of brGDGTs in loess deposited during OIS 4 and the beginning of OIS 3 (units L1LL2 and L1SS1 in Fig. 3) was below detection limit, so that environmental conditions could not be derived from GDGT-based proxies for this period. Since soil bacteria generally need sufficient moisture to thrive, and the brGDGT-producing organisms are sensitive to aridity (e.g. Peterse et al., 2012; Xie et al., 2012; Dirghangi et al., 2013), their presence below detection limit in this part of the sequence suggests that arid conditions prevailed during the interval between OIS 4 and the beginning of OIS 3. Indeed, also loess snail assemblages in the southern Carpathian Basin indicate very dry conditions and associated mosaic vegetation during the Last Glacial period (Marković et al., 2005, 2007). Moreover, the high sand percentage during OIS 4 (around 20\%), indicate that the environment was dynamic, characterized by strong winds and cold conditions (Fig. 3; Hatté et al., 2013).

Although no more information on climate variability during OIS 4 and the beginning of OIS 3 can be obtained from biomarkers in this part of the Surduk sequence, it can be inferred that the typical loess deposited at Surduk does not contain any brGDGTs upon deposition. This implies that the brGDGTs that are detected in this section are not transported and deposited in association with the dust, but are produced in situ, post deposition. Hence, the temperature-, pH- and BIT-index records are most likely not disturbed by allochthonous brGDGTs from the loess source region, so that these records thus truly reflect past variations in the climate around Surduk. This is in line with the absence of detectable GDGTs in windblown dust collected from the Chinese Loess Plateau, which indicated that the vast majority of the brGDGTs in loess-paleosols sequences must be produced in situ (Gao et al., 2012). That the contribution of pre-aged loess-associated lipids is also negligible in the Vojvodina region becomes evident from a recent study showing that ${ }^{14} \mathrm{C}$ ages of plant waxes in the nearby Crvenka sequence (Fig. 1) are similar to the luminescence ages and stratigraphy of the loess layer from which they were extracted (Häggi et al., 2014). These results provide independent evidence for excluding a modern overprint of the lipid signature stored in loess-paleosol sequences.

\subsubsection{OIS 3-OIS 1}

The interval between $\sim 1200 \mathrm{~cm}$ depth and the top of the sequence is presumed to be most suitable for the generation of reliable climate records because there are no indications for post-depositional mixing of the sediment, as can be deduced from the variability in the $\delta^{13} \mathrm{C}$ record (Fig. 4) and the presence of laminated structures (Antoine et al., 2009). Furthermore, brGDGTs were abundant in this section, enabling calculation of the paleoclimate proxies. This section was deposited with a high sedimentation rate, giving the opportunity to study this time interval in high resolution.

The brGDGT-derived temperatures gradually decrease from $14{ }^{\circ} \mathrm{C}$ to $7{ }^{\circ} \mathrm{C}$ into OIS 3 , remain stable until the start of OIS 2 , and then gradually increase to $20^{\circ} \mathrm{C}$ at the end of OIS 2 (Fig. 4). The brGDGT-derived temperature record indicates a substantial degree of atmospheric warming in the Surduk region over the last deglaciation. Although absolute temperature records for this region are limited, hindering direct comparison, the relatively large degree of warming may (partly) be the result of a seasonal bias. BrGDGTs in Chinese loess, for example, have been assumed to be mainly produced in summer, when warm and wet conditions prevail, providing good growing conditions for the soil bacteria that produce them, as opposed to during the cold and dry winter climate. The brGDGT-based temperature records for this area have consequently been interpreted as summer air temperatures (e.g. Peterse et al., 2011). Nevertheless, Weijers et al. (2011) found no seasonal trends in the concentration and distribution of branched GDGTs in soils from several locations at mid-latitudes, probably due to the availability of sufficient soil moisture year round. Despite unambiguity in the interpretation of absolute temperatures, the trends of the temperature records based on brGDGTs in loess sections deposited at a high rate have been shown to reliably reflect past temperature variations (e.g. Peterse et al., 2011, 2014; Jia et al., 2013). However, the fact that the reconstructed temperatures are above modern mean annual air temperature from around the middle of OIS 2 onwards (Fig. 4) suggests that indeed seasonal temperatures instead of mean annual air temperatures are recorded by the brGDGTs in this area. This assumption is supported by the fact that the brGDGT-based temperatures resemble the summer temperatures derived from snail assemblages in the nearby Irig loess sequence (Marković et al., 2007).

The relatively early onset of atmospheric warming in the Surduk temperature record (Fig. 4) may be a result of mixing of the organic carbon, as may be inferred from the interval of approximately the same ${ }^{14} \mathrm{C}$ 

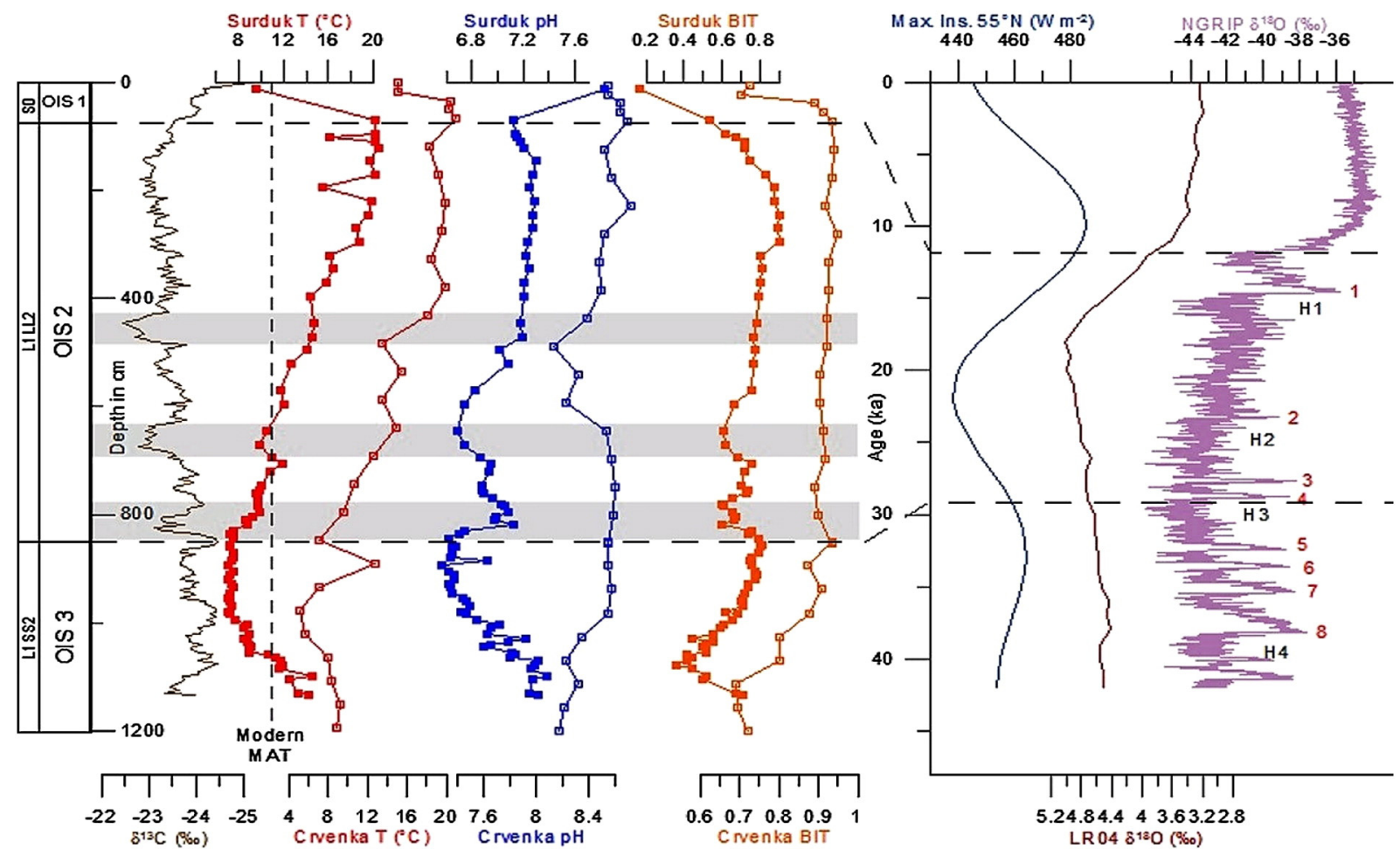

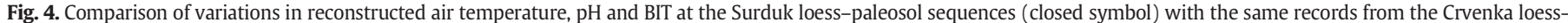

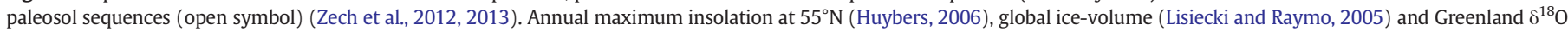

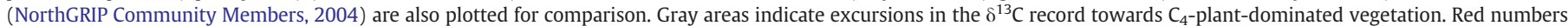
indicate the timing of Dansgaard-Oeschger Events, Heinrich Events are indicated in black.

dates from 5 to $10 \mathrm{~m}$ in the sequence (Hatté et al., 2013). This is interpreted as a period of high sedimentation rate, but may also be explained by mixing of the ${ }^{14} \mathrm{C}$ signal and also the GDGT signal, as was proposed by Zech et al. (2012) as the 'growth depth effect', resulting in a seemingly earlier warming in the reconstructed temperature record. However, mixing of the soil organic carbon pool should have resulted in smoothening of all records, whereas the $\delta^{13} \mathrm{C}$ record shows a clear variability with depth (Fig. 4). Also, a recent study by Häggi et al. (2014) excludes an overprint of the original lipid signature with a modern overprint based on ${ }^{14} \mathrm{C}$ dating of biomarkers in loess, giving more confidence that the reconstructed temperature record truly reflects air temperature at that time.

When comparing the temperature trends in this period between the second part of OIS 3 and OIS 1 to established Northern Hemisphere climate records, direct links seem to be missing (Fig. 4). For example, Northern Hemisphere annual maximum insolation is expected to positively correlate with continental air temperature, as was observed for Chinese loess sections (e.g. Peterse et al., 2014). Surprisingly, this link is not so clear in the Surduk sequence. The insolation maximum around $32 \mathrm{ka}$ is not reflected in the temperature record, as well as the insolation minimum around $22 \mathrm{ka}$, where a gradual increase in temperature in OIS 2 is recorded. The decoupling of insolation and temperature suggests that insolation is not the main driving factor for temperature change in the Surduk region. Additionally, despite the high resolution of our temperature record, no characteristic Northern Hemisphere climate events can be observed in the temperature curve, compared to those in e.g. the Greenland ice core $\delta^{18} \mathrm{O}$ record (Fig. 4). This suggests that the continental air temperature changes around Surduk are likely driven by regional factors rather than by $\mathrm{NH}$ climate forcings.

The waxing and waning of ice sheets on the Northern Hemisphere, represented by the global benthic stack (Lisiecki and Raymo, 2005; Fig. 4), have been suggested to play a role in driving the timing of hydrological processes in East Asia (Peterse et al., 2014; Caley et al., 2014), but do not show a clear correlation with the reconstructed moisture availability in the Surduk region, again indicating that regional drivers are more important controls on climate variability in this area.

Support for a regional climate driver comes from comparison of the Surduk temperature and precipitation records with those of the nearby Crvenka sequence (Zech et al., 2012, 2013; location in Fig. 1, comparison in Fig. 4). The sections were linked by relating their stratigraphy based on the classification proposed by Marković et al. (2015). The temperature- and BIT-index records of both sequences have a similar pattern, while the $\mathrm{pH}$ records show different trends and absolute values, with higher values over the whole Crvenka sequence (Fig. 4). An important part of this difference may be explained by the difference in analytical methods and transfer functions used to generate the records. Zech et al. $(2012,2013)$ used the original soil calibration of Weijers et al. (2007a), while in this study the proxy calibration of De Jonge et al. (2014), based on improved chromatography was used. The latter method has correlated $\mathrm{pH}$ to the abundance of 6-methyl brGDGTs, whereas the original calibration derives $\mathrm{pH}$ based on the degree of cyclisations. This difference may have caused part of the discrepancy between the $\mathrm{pH}$ records of the Surduk sequence and the Crvenka sequence. Alternatively, also the $\mathrm{CaCO}_{3}$-percentage of the substrate, which is on average $6 \%$ higher at Crvenka than at Surduk, may have played a role.

Considering that the temperature- and BIT-index records from the Surduk sequence and the Crvenka sequence show practically the same pattern, the early warming and relatively high absolute (summer) air temperatures seem to be valid. These findings support the idea that parts of southeastern Europe have served as refugia for temperate trees during glacials (Panagiotopoulos et al., 2013). The two independently generated records give confidence that the climate in this area indeed did not necessarily follow known Northern Hemisphere climate patterns, but that regional factors were of more importance, possibly because the Carpathian Basin is isolated inland by surrounding mountains (cf. Buggle et al., 2013). 


\subsection{Implications for past vegetation change in the Vojvodina region}

Generally, loess deposition is associated with cold and dry glacial climate conditions with scarce vegetation. In contrast, soil formation is associated with warmer and generally wetter climate with temperate forest vegetation (e.g. Kukla, 1987; Derbyshire et al., 1997; Muhs and Bettis, 2003). On the contrary, Zech et al. (2009) stated that full glacial conditions in the Carpathian Basin were not generally characterized by treeless, cold steppic environments. Instead, they suggested that open taiga forest prevailed even on the loess plateau. Snail assemblages studied in loess-paleosol sequences in this region indicate mosaic-like vegetation patterns (Marković et al., 2005), demonstrating the complexity of reconstructing an average climate history and associated vegetation changes for this region. In the Surduk area, vegetation change over the last $50 \mathrm{ka}$ was characterized by three periods of increased $\mathrm{C}_{4}$ plant abundance (gray areas in Fig. 4). Moisture limitation was proposed as main driver for these vegetation changes (Hatté et al., 2013) and indeed, albeit limited, the excursions are best recorded in the BIT record (Fig. 4), while the air temperature record does not show any clear variations with increased $\mathrm{C}_{4}$-vegetation. Moisture stress thus seems to be the main factor driving the excursions to $\mathrm{C}_{4}$-vegetation around Surduk and can either be caused by actual drought or by a change in the seasonal pattern of rainfall. However, the $\delta^{13} \mathrm{C}$ record of the Belotinac loess paleosol sequence (Obreht et al., 2014) does not support this pattern. But, it must be stressed that the Carpathian Basin is a complicated region with mosaic vegetation, as stated by this apparent contradiction.

\section{Conclusions}

The application of GDGT-based proxies on the Surduk loess-paleosol sequence in the Southeastern part of the Carpathian basin has resulted in continuous high-resolution records of air temperature and moisture availability over the last 40,000 years. The temperature record indicates that the timing of atmospheric warming does not directly correlate with insolation or established climate records for the Northern Hemisphere, instead the record may reflect summer temperatures instead of mean annual temperatures, or regional factors are of more importance, possibly because the Carpathian Basin is isolated inland by surrounding mountains. The reliability of the temperature record is supported by similar records from the nearby Crvenka loess section. Therefore, the existence of a regional climate in this part of Southwestern Europe may be a result of its geographical location, in which it is protected from Northern Hemisphere-influences by surrounding mountains. The periods of increased aridity indicated by the BIT record of the Surduk sequence largely match with episodes of increased $\mathrm{C}_{4}$ vegetation, indicating that moisture availability rather than temperature is the most likely driving factor for these events.

\section{Acknowledgements}

We would like to thank Igor Obreht and an anonymous reviewer for constructive comments that have improved our paper. Dominika Kasjaniuk, Anita van Leeuwen (UU), and Ellen Hopmans (NIOZ) are thanked for analytical support. This study was made possible by NWO grant \#834.11.006, which enabled the purchase of the UHPLC-MS system used for GDGT analyses. F. Peterse acknowledges financial support from NWO-Veni grant \#863.13.0016. Samples were taken within to the French ANR-ACTES project (ANR-08-BLAN-0227).

\section{Appendix A. Supplementary data}

Supplementary data to this article can be found online at http://dx. doi.org/10.1016/j.palaeo.2016.02.013.

\section{References}

An, Z., 2000. The history and variability of the East Asian paleomonsoon climate. Quat. Sci. Rev. 19, 171-187

Antoine, P., Rousseau, D.D., Zöller, L., Lang, A., Munaut, A.V., Hatté, C., Fontugne, M., 2001. High-resolution record of the last interglacial-glacial cycle in the Nussloch loess palaeosol sequences, Upper Rhine Area, Germany. Quat. Int. 76/77, 211-229.

Antoine, P., Rousseau, D.-D., Fuchs, M., Hatté, C., Gauthier, C., Marković, S.B., Jovanović, M., Gaudenyi, T., Moine, O., Rossignol, J., 2009. High-resolution record of the last climatic cycle in the Southern Carpathian Basin (Surduk, Vojvodina, Serbia). Quat. Int. 198, 19-36.

Buggle, B., Hambach, U., Glaser, B., Gerasimenko, N., Marković, S, Glaser, I, Zöller, L, 2009. Stratigraphy, and spatial and temporal paleoclimatic trends in Southeastern/Eastern European loess-paleosol sequences. Quat. Int. 196, 86-106.

Buggle, B., Hambach, U., Kehl, M., Marković, S.B., Zöller, L., Glaser, B., 2013. The progressive evolution of a continental climate in SE-Central European lowlands during the Middle Pleistocene recorded in loess paleosol sequences. Geology 41, 771-774.

Caley, T., Roche, D.M., Renssen, H., 2014. Orbital Asian summer monsoon dynamics revealed using an isotope-enabled global climate model. Nat. Commun. $\mathbf{5}$

De Jonge, C., Hopmans, E.C., Stadnitskaia, A., Rijpstra, W.I.C., Hofland, R., Tegelaar, E., Sinninghe Damsté, J.S., 2013. Identification of novel penta- and hexamethylated branched glycerol dialkyl glycerol tetraethers in peat using HPLC-MS2562, GC-MS and GC-SMB-MS. Org. Geochem. 54, 78-82.

De Jonge, C., Hopmans, E.C., Zell, C.I., Jung-Hyun, K., Schouten, S., Sinninghe Damsté, J.S., 2014. Occurrence and abundance of 6-methyl branched glycerol dialkyl glycerol tetraethers in soils: Implications for palaeoclimate reconstruction. Geochim. Cosmochim. Acta 141, 97-112.

Derbyshire, E., Kemp, R.A., Meng, X., 1997. Climate change, loess and palaeosols: proxy measures and resolution in North China. J. Geol. Soc. 154, 793-805.

Dirghangi, S.S., Pagani, M., Hren, M.T., Tipple, B.J., 2013. Distribution of glycerol dialkyl glycerol tetraethers in soils from two environmental transects in the USA. Org. Geochem. 59, 49-60.

Ducić, V., Radovanović, M., 2005. Klima Srbije. Zavod za izdavanje udžbenika, Beograd (In Serbian with English summary).

Gao, L., Nie, J.S., Clemens, S., Liu, W.G., Sun, J.M., Zech, R., Huang, Y.S., 2012. The importance of solar insolation on the temperature variations for the past $110 \mathrm{kyr}$ on the Chinese Loess Plateau. Palaeogeogr. Palaeoclimatol. 317, 128-133.

Haase, D., Fink, J., Haase, G., Ruske, R., Pécsi, M., Richter, H., Altermann, M., Jäger, K.-D., 2007. Loess in Europe-its spatial distribution based on a European Loess Map, scale 1:2,500,000. Quaternary Science Reviews 26, 1301-1312.

Häggi, C., Zech, R., McIntyre, C., Zech, M., Eglinton, T.I., 2014. On the stratigraphic integrity of leaf-wax biomarkers in loess paleosols. Biogeosciences 11, 2455-2463.

Fuchs, M., Rousseau, D.-D., Antoine, P., Hatté, C., Gauthier, C., Marković, S., Zoeller, L., 2008. Chronology of the Last Climatic Cycle (Upper Pleistocene) of the Surduk loess sequence, Vojvodina, Serbia. Boreas 37, 66-73.

Hatté, C., Gauthier, C., Rousseau, D.D., Antoine, P., Fuchs, M., Lagroix, F., Marković, B., Moine, O., Sima, A., 2013. Excursions to C4 vegetation recorded in the Upper Pleistocene loess of Surduk (Northern Serbia): an organic isotope geochemistry study. Clim. Past 9, 1001-1014.

Hopmans, E.C., Weijers, J.W.H., Schefuß, E., Herfort, L., Sinninghe Damsté, J.S., Schouten, S., 2004. A novel proxy for terrestrial organic matter in sediments based on branched and isoprenoid tetraether lipids. Earth Planet. Sci. Lett. 224, 107-116.

Hopmans, E.C., Schouten, S., Sinninghe Damsté, J.S., 2016. The effect of improved chromatography on GDGT-based paleoproxies. Org. Geochem. 93, 1-6.

Hrnjak, I., Lukić, T., Gavrilov, M.B., Marković, S.B., Unkašević, M., Tošić, I., 2014. Aridity in Vojvodina, Serbia. Theor. Appl. Climatol. 115, 323-332.

Huybers, P., 2006. Early Pleistocene glacial cycles and the integrated summer insolation forcing Science $313,508-511$.

Jia, G., Rao, Z., Zhang, J., Li, Z., Chen, F., 2013. Tetraether biomarker records from a loesspaleosol sequence in the western Chinese Loess Plateau. Front. Microbiol. 4, 199.

Kukla, G., 1987. Loess stratigraphy in central China. Quat. Sci. Rev. 6, 191-219.

Lisiecki, L.E., Raymo, M.E., 2005. A Pliocene-Pleistocene stack of 57 globally distributed benthic d180 records. Paleoceanography 20, PA1003.

Marković, S.B., McCoy, W.D., Oches, E.A., Savić, S., Gaudenyi, T., Jovanović, M., Stevens, T., Walther, R., Ivanišević, P., Galić, Z., 2005. Paleoclimate record in the Upper Pleistocene loess-paleosol sequence at Petrovaradin brickyard (Vojvodina, Serbia). Geol. Carpath. 56 (6), 545-552.

Marković, S.B., Oches, E.A., McCoy, W.D., Frechen, M., Gaudenyi, T., 2007. Malacological and sedimentological evidence for "warm" glacial climate from the Irig loess sequence, Vojvodina, Serbia. Geochem. Geophys. Geosyst. 8, Q09008. http://dx.doi. org/10.1029/206GC001565.

Marković, S.B., Bokhorst, M.P. Vandenberghe, J., McCoy, W.D., Oches, E.A., Hambach, U., Gaudenyi, T., Jovanović, M., Zöller, L., Stevens, T., Machalett, B., 2008. Late Pleistocene loess-paleosol sequences in the Vojvodina Region, north Serbia. J. Quat. Sci. 23, $73-84$.

Marković, S.B., Stevens, T., Kukla, G.J., Hambach, U., Fitzsimmons, K.E., Gibbard, P., Buggle, B., Zech, M., Guo, Z., Hao, Q., Wu, H., O'Hara Dhand, K., Smalley, I.J., Újvári, G., Sümegi, P., Timar-Gabor, A., Veres, D., Sirocko, F., Vasiljević, D.A., Jary, Z., Svensson, A., Jović, V., Lehmkuhl, F., Kovács, J., Svirčev, Z., 2015. Danube loess stratigraphy - towards a panEuropean loess stratigraphic model. Earth Sci. Rev. 148, 228-258.

Muhs, D.R., Bettis III, E.A., 2003. Quaternary loess-paleosol sequences as examples of climate-driven sedimentary extremes. In: Chan, M.A. Archer, A.W. (Eds.), Extreme Depositional Environments: Mega End Members in Geologic Time: Boulder, Colorado. Geological Society of America Special Paper 370, pp. 53-74.

NorthGRIP Community Members, 2004. High-resolution record of Northern Hemisphere climate extending into the last interglacial period. Nature 431, 147-151. 
Obreht, I., Buggle, B., Catto, N., Marković, S.B., Bösel, S., Vandenberghe, D.A.G., Hambach, U., Svirčev, Z., Lehmkuhl, F., Basarin, B., Gavrilov, M.B., Jović, V., 2014. The Late Pleistocene Belotinac section (southern Serbia) at the southern limit of the European loess belt: environmental and climate reconstruction using grain size and stable C and N isotopes. Quat. Int. 334-335, 10-19.

Panagiotopoulos, K., Aufgebauer, A., Schäbitz, F., Wagner, B., 2013. Vegetation and climate history of the Lake Prespa region since the Lateglacial. Quat. Int. 293, 157-169.

Peterse, F., Prins, M.A., Beets, C.J., Troelstra, S.R., Zheng, H., Gu, Z., Schouten, S., Sinninghe Damsté, J.S., 2011. Decoupled warming and monsoon precipitation in East Asia over the last deglaciation. Earth Planet. Sci. Lett. 301, 256-264.

Peterse, F., van der Meer, J., Schouten, S., Weijers, J.W.H., Fierer, N., Jackson, R.B., Kim, J.-K., Sinninghe Damsté, J.S., 2012. Revised calibration of the MBT-CBT paleotemperature proxy based on branched tetraether membrane lipids in surface soils. Geochim. Cosmochim. Acta 96, 215-229.

Peterse, F., Martínez-García, A., Zhou, B., Beets, C.J., Prins, M.A., Zheng, H., Eglinton, T.I., 2014. Molecular records of continental air temperature and monsoon precipitation variability in East Asia spanning the past 130,000 years. Quat. Sci. Rev. 83, 76-82.

Petit, J.R., Jouzel, J., Raynaud, D., Barkov, N.I., Barnola, J.M., Basile, I., Bender, M., Chappellaz, J., Davis, J., Delaygue, G., Delmotte, M., Kotlyakov, V.M., Legrand, M., Lipenkov, V., Lorius, C., Pépin, L., Ritz, C., Saltzman, E., Stievenard, M., 1999. Climate and atmospheric history of the past 420,000 years from the Vostok Ice Core, Antarctica. Nature 399, 429-436.

Rousseau, D.-D., Antoine, P., Hatté, C., Lang, A., Zöller, L., Fontugne, M., Ben Othman, D., Luck, J.M., Moine, O., Labonne, M., Bentaleb, I., Jolly, D., 2002. Abrupt millennial climatic changes from Nussloch (Germany) Upper Weichselian eolian records during the Last Glaciation. Quat. Sci. Rev. 21, 1577-1582.

Rousseau, D.-D., Sima, A., Antoine, P., Hatté, C., Lang, A., Zöller, L., 2007. Link between European and North Atlantic abrupt climate changes over the last glaciation. Geophys. Res. Lett. 34.

Shackleton, N.H., 1969. The last interglacial in the marine and terrestrial records. Proc. R. Soc. Lond. B 174, 135-154.

Stevens, T., Marković, S.B., Zech, M., Hambach, U., Sümegi, P., 2011. Dust deposition and climate in the Carpathian Basin over an independently dated last glacial-interglacial cycle. Quat. Sci. Rev. 30, 662-681.
Tošić, I., Hrnjak, I., Gavrilov, M.B., Unkašević, M., Marković, S.B., Lukić, T., 2014. Annual and seasonal variability of precipitation in Vojvodina Serbia. Theor. Appl. Climatol. 117, 331-341.

Wang, H., Liu, W., Zhang, C.L., 2014. Dependence of the cyclization of branched tetraethers (CBT) on soil moisture in the Chinese Loess Plateau and the adjacent areas: implications for palaeorainfall reconstructions. Biogeosci. Discuss. 11, 10,015-10,043.

Weijers, J.W.H., Schouten, S., Hopmans, E.C., Geenevasen, J.A.J., David, O.R.P., Coleman, J.M., Pancost, R.D., Sinninghe Damsté, J.S., 2006. Membrane lipids of mesophilic anaerobic bacteria thriving in peats have typical archaeal traits. Environ. Microbiol. 8, 648-657.

Weijers, J.W.H., Schouten, S., van Den Donker, J.C., Hopmans, E.C., Sinninghe Damsté, J.S 2007a. Environmental controls on bacterial tetraether membrane lipid distribution in soils. Geochim. Cosmochim. Acta 71, 703-713.

Weijers, J.W.H., Schefuß, E., Schouten, S., Sinninghe Damsté, J.S., 2007b. Coupled thermal and hydrological evolution of tropical Africa over the last deglaciation. Science 315, 1701-1704.

Weijers, J.W.H., Bernhardt, B., Peterse, F., Werne, J.P., Dungait, J.A.J., Schouten, S., Sinninghe Damsté, J.S., 2011. Absence of seasonal patterns in MBT-CBT indices in mid-latitude soils. Geochim. Cosmochim. Acta 73, 3179-3190.

Xie, S., Pancost, R.D., Chen, L., Evershed, R.P., Yang, H., Zhang, K., Huang, J., Xu, Y., 2012. Microbial lipid records of highly alkaline deposits and enhanced aridity associated with significant uplift of the Tibetan Plateau in the Late Miocene. Geology 40, 291-294.

Zech, M., Buggle, B., Leiber, K., Marković, S.B., Glaser, B., Hambach, U., Huwe, B., Stevens, T. Sümegi, P., Wiesenberg, G.L.B., Zöller, L., 2009. Reconstructing Quaternary vegetation history in the Carpathian Basin, SE Europe, using n-alkane biomarkers as molecular fossils. J. Quat. Sci. 58, 148-155.

Zech, R., Gao, L., Tarozo, R., Huang, Y., 2012. Branched glycerol dialkyl glycerol tetraethers in Pleistocene loess-paleosol sequences: three case studies. Org. Geochem. 53, 38-44.

Zech, R., Zech, M., Marković, S.B., Hambach, U., Huang, Y., 2013. Humid glacials, arid interglacials? Critical thoughts on pedogenesis and paleoclimate based on multi-proxy analyses of the loess-paleosol sequence Crvenka, Northern Serbia. Palaeogeogr. Palaeoclimatol. Palaeoecol. 387, 165-175. 